\title{
New sight: rapid monitor of intracellular water information in plant leaves based on electrophysiological parameters
}

C. Zhang

Jiangsu University

Yanyou Wu ( $\nabla$ wuyanyou@mail.gyig.ac.cn )

Institute of Geochemistry Chinese Academy of Sciences https://orcid.org/0000-0002-0940-4349

Y. Su

Guizhou Vocational College of Agriculture

D.K. Xing

Jiangsu University

Y. Dai

Guizhou Vocational College of Agriculture

\section{Y.S. Wu}

Institute of Geochmistry Chinese Academy of Sciences

\section{Fang}

Institute of Geochemistry Chinese Academy of Sciences

\section{Research}

Keywords: intracellular water, monitor, electrophysiological parameters, water-holding capacity, water use efficiency.

Posted Date: April 29th, 2020

DOI: https://doi.org/10.21203/rs.3.rs-25186/v1

License: (c) (i) This work is licensed under a Creative Commons Attribution 4.0 International License. Read Full License 
1 New sight: rapid monitor of intracellular water information in plant leaves based on 2 electrophysiological parameters

3 Cheng Zhang ${ }^{1,2}$, Yanyou $\mathrm{Wu}^{2,}{ }^{2 *}$, Yu Su ${ }^{3}$, Dingke Xing ${ }^{1}$, Yi Dai ${ }^{3}$, Yansheng $\mathrm{Wu}^{2}$ and Lei Fang ${ }^{2}$

4

$5 \quad$ *Correspondence: Yanyou Wu, Email: wuyanyou@mail.gyig.ac.cn, Tel: +86 085184391746

6 The work was carried out at State Key Laboratory of Environmental Geochemistry, Institute of Geochemistry,

7 Chinese Academy of Sciences.

8 Address: No. 99 Lincheng West Road, Guanshanhu District, Guiyang, Guizhou Province 550081, P.R. China

9 Full list of author information is available at the end of the article. 
10 New sight: rapid monitor of intracellular water information in plant leaves based on electrophysiological parameters

\section{Abstract}

Background: Intracellular water in plant leaves is paramount importance to physiological and biochemical processes.

14 Water changes trigger the rapid response of plant electrophysiological information. In this study, plant electrophysiological information was firstly used to rapid monitor intracellular water information in plant leaves.

16 Results: Based on the thermodynamics laws, the fitting equations between plant electrophysiological parameters and 17 clamping force were innovative established. Subsequently, leaf intrinsic electrophysiological parameters, 18 intracellular water-holding capacity (IWHC), water use efficiency (IWUE), water-holding time (IWHT) and water 19 transfer rate (WTR), were firstly developed and applied. The results show that the leaves of Broussonetia papyrifera 20 in the cultivated soil had higher IWHC, WTR and water content than in the moderate rocky desertification soil. The 21 leaf IWHC, WTR and water content of the herbaceous plants were higher than that of the woody plants. Solanum 22 tuberosum had higher leaf IWHC, WTR and lower IWUE, IWHT, as compared to Capsicum annuum. Conclusions: These indexes strongly reveal the life phenomenon of the intracellular water metabolism in plant leaves. This study highlights that the online electrophysiological parameters promise a new sight for intracellular water metabolism in plants.

26 Keywords: intracellular water, monitor, electrophysiological parameters, water-holding capacity, water use 27 efficiency. 


\section{Background}

Water in plant leaves, an indispensable medium, plays a key role in physiological and biochemical processes including photosynthesis, evapotranspiration and net primary production etc. [1,2]. Plant leaves are the most sensitive organ to various metabolisms related to water, such as water stress reducing leaf area and closures of stomata, consequently reduces photosynthesis and affects metabolism, resulting in stunted growth [3,4]. Most $(95 \% \sim 99 \%)$ of the water in plant leaves dissipates through transpiration, and a small amount $(1 \% \sim 5 \%)$ of that is retained in leaf cells to support plant growth [5]. Generally, the water use efficiency of plants is expressed by the ratio $(\mathrm{Pn} / \mathrm{Tr})$ of net photosynthetic rate $(\mathrm{Pn})$ to transpiration rate $(\mathrm{Tr})$ and it mainly reveals the water consumption of plant transpiration [6]. However, this water use efficiency can't directly reflect the utilization of the intracellular water. Moreover, the metabolic utilization quality of this precious intracellular water $(1 \% \sim 5 \%)$ is paramount importance to many physiological and biochemical processes, such as photosynthesis, respiration, organic synthesis and decomposition etc. To the best of our knowledge, no work has hitherto been conducted for the directly quantitative detection of the intracellular water information in plant leaves. Therefore, it is extremely relevant and urgent to develop, especially, in situ and rapid monitoring technology for the intracellular water information in plant leaves.

Many techniques capable of monitoring leaf water content have been reported, such as spectrometry, stable oxygen and hydrogen isotope, water potential and drying $[1,7,8]$. However, the leaf water contents can't directly reflect the dynamic information of intracellular water in plant leaves, and the limitations of such methods in terms of on-field, price, complex or accuracy have limited to their application in situ. Recently, plant electrophysiological information has been applied to study water information of plants [9-14]. For instance, Javed et al. [11] evaluated irrigation effects using diluted salted water based on electrophysiological properties. Zhang et al. [12] demonstrated electrophysiological properties of the plants reflecting their ability to resist drought and defined leaf tensity to represent plant drought resistance. Xing et al. $[13,14]$ used leaf tensity to rapid determine water requirement information in Brassica napus L. and predicted re-watering time of Orychophragmus violaceus L. These findings demonstrate that plant electrophysiological information display potential to become an in situ, rapid, accurate and real-time monitoring technique for the water information of plant leaves. However, they still can't obtain the transportation, water-holding and utilization information of the intracellular water in plant leaves.

In mesophyll cells, both cells and organelles are surrounded by cell membrane. The cell membrane is mainly composed of lipids (mainly phospholipids, accounting for about 50\%), proteins (accounting for about $40 \%$ ) and sugars (accounting for about 2\% 10\%) etc. [5]. Phospholipid bilayer is the basic scaffold of cell membrane and it can be divided into three layers, which are two electron density bands (hydrophilic part) about $2.5 \mathrm{~nm}$ thick on the 
inside and outside of the membrane, as well as transparent band (hydrophobic part) about $2.5 \mathrm{~nm}$ thick in the middle 5,15. Therefore, the cell can be regarded as a concentric sphere capacitor, which has the function of both inductor and resistor because of the outer and inner proteins in cell membrane [16]. Mature leaves which account for a high proportion of plants determine and reflect plant water metabolism, all the fully expanded leaves are mature leaves and their cells have central vacuoles. The vacuoles of the mature leaf cells account for $50 \% \sim 90 \%$ of the cell volume, and their main component is water. Moreover, the component of protoplasm is also mainly water. Thus, the vacuole volume can basically represent the water-holding capacity of plant leaves.

The physiological capacitance $(\mathrm{C})$, impedance $(\mathrm{Z})$ and capacitive reactance $(\mathrm{Xc})$ are related to the cell sap concentration, and the variation of the cell sap concentration is caused by vacuole volume. Consequently, plant electrophysiological information can represent the water information of plant leaves. Mesophyll cell can be regarded as a concentric sphere capacitor, the work converted by Gibbs free energy characterizes the mesophyll cells capacitor energy which can be used to describe the relationship between the leaf $\mathrm{C}$ and clamping force. Moreover, Nernst equation characterizes the diffusion potential of dielectric substances inside and outside of cell membrane which can be used to describe the relationships between the leaf Z, Xc and clamping force. According to Gibbs free energy and Nernst equations, the fitting equations between the $\mathrm{C}, \mathrm{Z}, \mathrm{Xc}$ of plant leaves and clamping force were established. The dynamic information of intracellular water utilization in plant leaves based on the electrophysiological parameters was defined, and that of various plants growing in different habitats were analyzed. This study aims at providing a novel and in situ method for rapid determination of the intracellular water status of plant leaves.

\section{Results}

\section{The relationship model construction of clamping force (F) and leaf $\mathrm{C}, \mathrm{Z}$ and $\mathrm{Xc}$.}

The cell sap solute in plant leaf was used as the dielectric, and a parallel-plate capacitor sensor was formed by sandwiching the leaf between the two plates of the parallel-plate capacitor. The leaf $\mathrm{C}, \mathrm{Z}$ and $\mathrm{Xc}$ varied with the cell sap concentration in plant leaf, and the variation of the cell sap concentration was caused by the water status in leaf cell [13]. However, different clamping force would inevitably lead to the change of cell sap concentration in plant leaf. Different clamping force could be achieved by adding iron block. Moreover, the plant electrical signals obtained by traditional needling method often become less reproducible and comparable due to different environment, measuring people and other factors [17], as well as needling injury directly changes the electrical signals, resulting in their low authenticity. In order to obtain comparable and reproducible plant electrophysiological information, the models of clamping force and leaf $\mathrm{C}, \mathrm{Z}$ and $\mathrm{Xc}$ were constructed. According to the first law of thermodynamics, the work done by clamping force obeyed the Gibbs free energy equation: 
where $\Delta \mathrm{G}=$ Gibbs free energy $(\mathrm{J}), \Delta \mathrm{H}=$ internal energy of leaf cells system $(\mathrm{J}), \mathrm{P}=$ pressure intensity of on leaf cells $(\mathrm{Pa}), \mathrm{V}=$ cell volume $\left(\mathrm{m}^{3}\right)$. $\mathrm{P}$ could be calculated by the pressure intensity formula:

$$
\mathrm{P}=\frac{\mathrm{F}}{\mathrm{S}}
$$

where $\mathrm{F}=$ clamping force $(\mathrm{N}), \mathrm{S}=$ effective area of electrode plate $\left(\mathrm{m}^{2}\right)$. And $\mathrm{F}$ could be calculated by the gravity formula:

$$
\mathrm{F}=(\mathrm{M}+\mathrm{m}) \mathrm{g}
$$

where $\mathrm{M}=$ iron block quality $(\mathrm{Kg}), \mathrm{m}=$ the quality of plastic rod and plate electrode $(\mathrm{Kg}), \mathrm{g}=9.8 \mathrm{~N} / \mathrm{kg}$. Mesophyll cells could be regarded as concentric sphere capacitors, the capacitors energy was:

$$
\mathrm{W}=\frac{1}{2} \mathrm{U}^{2} \mathrm{C}
$$

where $\mathrm{W}=$ capacitor energy $(\mathrm{J}), \mathrm{U}=$ test voltage $(\mathrm{V}), \mathrm{C}=$ physiological capacitance $(\mathrm{pF})$.

According to energy conservation theory, the capacitor energy equal to the work converted by Gibbs free energy, i.e. $\mathrm{W}=\Delta \mathrm{G}$. The relationship model of leaf $\mathrm{C}$ and clamping force $(\mathrm{F})$ was obtained:

$$
\mathrm{C}=\frac{2 \Delta \mathrm{H}}{\mathrm{U}^{2}}+\frac{2 \mathrm{~V}}{\mathrm{SU}^{2}} \mathrm{~F}
$$

It is assumed that $d$ represents the specific effective thickness of plant leaves, then $d=\frac{v}{S}$. Formula (5) was transformed into formula (6):

$$
\mathrm{C}=\frac{2 \Delta \mathrm{H}}{\mathrm{U}^{2}}+\frac{2 \mathrm{~d}}{\mathrm{U}^{2}} \mathrm{~F}
$$

Let $\mathrm{x}_{0}=\frac{2 \Delta \mathrm{H}}{\mathrm{U}^{2}}, \mathrm{~h}=\frac{2 \mathrm{~d}}{\mathrm{U}^{2}}$, formula (6) was transformed into formula (7):

$$
\mathrm{C}=\mathrm{x}_{0}+\mathrm{hF}
$$

Formula (7) is a linear model, where $\mathrm{x}_{0}$ and $\mathrm{h}$ are model parameters. Due to $\mathrm{h}=\frac{2 \mathrm{~d}}{\mathrm{U}^{2}}$, so $\mathrm{d}=\frac{\mathrm{U}^{2} \mathrm{~h}}{2}$.

The concentration of the dielectric substances which response to $\mathrm{Z}$ in the inside and outside of cell membrane determined the plant leaf $Z$. The external stimuli changed the membrane permeability of the dielectric substances and affected its concentration in the inside and outside of cell membrane. Under different clamping forces, the membrane permeability of the dielectric substances which respond to $\mathrm{Z}$ in plant cell membrane changed differently. Mesophyll cell can be regarded as a concentric sphere capacitor, and according to the third law of thermodynamics, the Nernst equation can be used to quantitatively describe the diffusion potential of dielectric substances inside and outside of cell membrane. Thus, the concentration differences of the dielectric substances which response to $\mathrm{Z}$ in the inside and outside of cell membrane obeyed Nernst equation and its expression as follows: 


$$
\mathrm{E}-\mathrm{E}^{0}=\frac{\mathrm{R}_{0} \mathrm{~T}}{\mathrm{n}_{\mathrm{Z}} \mathrm{F}_{0}} \ln \frac{\mathrm{Q}_{\mathrm{i}}}{\mathrm{Q}_{\mathrm{o}}}
$$
where $\mathrm{E}=$ electromotive force $(\mathrm{V}), \mathrm{E}^{0}=$ standard electromotive force $(\mathrm{V}), \mathrm{R}_{0}=$ gas constant $\left(8.314570 \mathrm{~J} \mathrm{~K}^{-1} \mathrm{~mol}^{-1}\right)$, $\mathrm{T}=$ thermodynamic temperature $(\mathrm{K}), \mathrm{Q}_{\mathrm{i}}=$ the concentration of the dielectric substances which response to $\mathrm{Z}$ in the cell membrane inside $\left(\mathrm{mol} \mathrm{L}^{-1}\right), \mathrm{Q}_{0}=$ the concentration of the dielectric substances which response to $\mathrm{Z}$ in the cell membrane outside $\left(\mathrm{mol} \mathrm{L}^{-1}\right), \mathrm{F}_{0}=$ faraday constant $\left(96485 \mathrm{C} \mathrm{mol}^{-1}\right), \mathrm{n}_{\mathrm{Z}}=$ transferred number of dielectric substances (mol).

The internal energy of electromotive force could be converted into pressure work and they had a direct relationship, $\mathrm{PV}=\mathrm{a} \mathrm{E}$, that was:

$$
P V=a E=a E^{0}+\frac{a R_{0} T}{n_{Z^{0}}} \ln \frac{Q_{i}}{Q_{o}}
$$

where $\mathrm{P}=$ pressure intensity of on leaf cells $(\mathrm{Pa}), \mathrm{a}=$ energy conversion coefficient of electromotive force, $\mathrm{V}=$ cell volume $\left(\mathrm{m}^{3}\right)$. And $\mathrm{P}=\frac{\mathrm{F}}{\mathrm{S}}$, where $\mathrm{F}=$ clamping force $(\mathrm{N}), \mathrm{S}=$ effective area of electrode plate $\left(\mathrm{m}^{2}\right)$.

For mesophyll cells, the sum of $\mathrm{Q}_{\mathrm{o}}$ and $\mathrm{Q}_{\mathrm{i}}$ is certain. $\mathrm{Q}_{\mathrm{i}}$ is directly proportional to the conductivity of the dielectric substances which response to $Z$, and the conductivity is the $Z$ reciprocal. Hence, $\frac{Q_{i}}{Q_{o}}$ could be expressed as $\frac{Q_{i}}{Q_{o}}=$ $131 \frac{\frac{J_{0}}{Z}}{\mathrm{Q}-\frac{J_{0}}{Z}}=\frac{\mathrm{J}_{0}}{\mathrm{QZ}-\mathrm{J}_{0}}$, where $\mathrm{J}_{0}=$ ratio coefficient of the conversion between $\mathrm{Q}_{\mathrm{i}}$ and $\mathrm{Z}, \mathrm{Q}=\mathrm{Q}_{\mathrm{o}}+\mathrm{Q}_{\mathrm{i}}$. So, formula (9) was transformed into formula (10):

$$
\frac{\mathrm{V}}{\mathrm{S}} \mathrm{F}=\mathrm{a} \mathrm{E}^{0}-\frac{\mathrm{aR} \mathrm{R}_{0} \mathrm{~T}}{\mathrm{n}_{\mathrm{Z}_{0}}} \ln \frac{\mathrm{QZ}-\mathrm{J}_{0}}{\mathrm{~J}_{0}}
$$

and

$$
\frac{\mathrm{a} \mathrm{R}_{0} \mathrm{~T}}{\mathrm{n}_{\mathrm{Z}} \mathrm{F}_{0}} \ln \frac{\mathrm{QZ}-\mathrm{J}_{0}}{\mathrm{~J}_{0}}=\mathrm{a} \mathrm{E}^{0}-\frac{\mathrm{V}}{\mathrm{S}} \mathrm{F}
$$

Formula (12) taken the exponents of both sides:

$$
\frac{\mathrm{QZ}-\mathrm{J}_{0}}{\mathrm{~J}_{0}}=\mathrm{e}^{\frac{\mathrm{n}_{\mathrm{Z}} \mathrm{F}_{0} \mathrm{E}^{0}}{\mathrm{R}_{0} \mathrm{~T}}} \mathrm{e}^{\left(-\frac{\mathrm{Vn}_{\mathrm{Z}} \mathrm{F}_{0}}{\mathrm{Sa} \mathrm{R}_{0} \mathrm{~T}} \mathrm{~F}\right)}
$$

further:

$$
\mathrm{Z}=\frac{\mathrm{J}_{0}}{\mathrm{Q}}+\frac{\mathrm{J}_{0}}{\mathrm{Q}} \mathrm{e}^{\frac{\mathrm{n}_{\mathrm{Z}} \mathrm{F}_{0} \mathrm{E}^{0}}{\mathrm{R}_{0} \mathrm{~T}}} \mathrm{e}^{\left(-\frac{\mathrm{Vn}_{\mathrm{Z}} \mathrm{F}_{0}}{\mathrm{Sa} \mathrm{R} \mathrm{R}_{0} \mathrm{~T}} \mathrm{~F}\right)}
$$

Due to $d=\frac{V}{S}$, formula (14) was transformed into:

$$
\mathrm{Z}=\frac{\mathrm{J}_{0}}{\mathrm{Q}}+\frac{\mathrm{J}_{0}}{\mathrm{Q}} \mathrm{e}^{\frac{\mathrm{n}_{\mathrm{Z}} \mathrm{F}_{0} \mathrm{E}^{0}}{\mathrm{R}_{0} \mathrm{~T}}} \mathrm{e}^{\left(-\frac{\mathrm{dn}_{\mathrm{Z}} \mathrm{F}_{0}}{\mathrm{a} \mathrm{R}_{0} \mathrm{~T}} \mathrm{~F}\right)}
$$


144 Order $\mathrm{y}_{0}=\frac{\mathrm{J}_{0}}{\mathrm{Q}}, \mathrm{k}_{1}=\frac{\mathrm{J}_{0}}{\mathrm{Q}} \mathrm{e}^{\frac{\mathrm{n}_{\mathrm{Z}_{0}} \mathrm{E}^{0}}{\mathrm{R}_{0} \mathrm{~T}}}, \mathrm{~b}_{1}=\frac{\mathrm{d} \mathrm{n}_{\mathrm{Z}_{0}}}{\mathrm{R}_{0} \mathrm{~T}}$, formula (15) was simply written:

$$
\mathrm{Z}=\mathrm{y}_{0}+\mathrm{k}_{1} e^{-\mathrm{b}_{1} \mathrm{~F}}
$$

where $\mathrm{y}_{0}, \mathrm{k}_{1}$ and $\mathrm{b}_{1}$ are model parameters.

When $\mathrm{F}=0$, the intrinsic impedance (IZ) of plant leaves could be obtained: $\mathrm{IZ}=\mathrm{y}_{0}+\mathrm{k}_{1}$.

Similar to Z, the model of clamping force and leaf Xc was constructed (Additional file 1):

$$
\mathrm{Xc}=\mathrm{p}_{0}+\mathrm{k}_{2} \mathrm{e}^{-\mathrm{b}_{2} \mathrm{~F}}
$$

where $\mathrm{p}_{0}, \mathrm{k}_{2}$ and $\mathrm{b}_{2}$ are model parameters.

When $\mathrm{F}=0$, the intrinsic capacitive reactance (IXc) of plant leaves could be calculated: $\mathrm{IXc}=\mathrm{p}_{0}+\mathrm{k}_{2}$. The intrinsic capacitance (IC) of plant leaves could also be gained: $\mathrm{IC}=\frac{1}{2 \pi f \mathrm{IXc}}$, where $\pi=3.1416, \mathrm{f}=$ frequency, $\mathrm{IXc}=$ intrinsic capacitive reactance.

\section{The water utilization parameters}

Cell is a spherical structure, and its growth is closely related to volume increase. The $\mathrm{C}$ of plant leaf cells can be calculated by the formula of the concentric spherical capacitor:

$$
\mathrm{Cc}=\frac{4 \pi \varepsilon R_{1} R_{2}}{R_{2}-R_{1}}
$$

where $\pi=3.1416, \mathrm{Cc}=$ capacitance of the concentric spherical capacitor $(\mathrm{pF}), \varepsilon=$ dielectric constant of electrolyte, $R_{I}=$ outer sphere radius $(\mathrm{m}), R_{2}=$ inner sphere radius (m). For a plant cell, $R_{2}-R_{I}$ is thickness of cell membrane, $R_{1} \approx R_{2}$, as well as $\varepsilon$ and the thickness of cell membrane are constant. Therefore, the cell volume $(\mathrm{Vc})$ has the following relationship with the cell C:

$$
\mathrm{Vc}=\alpha \sqrt{\mathrm{C}^{3}}
$$

The cell volume is positively correlated with the volume of its vacuole, and the main component of vacuole is water. In other words, the water-holding capacity of cells is directly proportional to $\sqrt{\mathrm{C}^{3}}$. Therefore, $\sqrt{\mathrm{C}^{3}}$ can represent the water-holding capacity of plant leaves. The intracellular water-holding capacity (IWHC) of plant leaves was obtained according to formula (20):

$$
\mathrm{IWHC}=\sqrt{(\mathrm{IC})^{3}}
$$

The specific effective thickness (d) of plant leaves represents the cells growth, and the water-holding capacity supports plant cells growth. Therefore, the intracellular water use efficiency (IWUE) of leaves was represented as formula (21): 


$$
\text { IWUE }=\frac{\mathrm{d}}{\mathrm{IWHC}}
$$

According to Ohm's law, $\mathrm{I}_{\mathrm{Z}}=\mathrm{U} / \mathrm{Z}$, where $\mathrm{I}_{\mathrm{Z}}=$ physiological current $(\mathrm{A}), \mathrm{U}=$ test voltage $(\mathrm{V}), \mathrm{Z}=$ physiological impedance $(\Omega)$. At the same time, the current is equal to the product of capacitance and the differential of voltage in time as formula (22):

$$
\mathrm{I}_{\mathrm{Z}}=\mathrm{IC} \times \int \mathrm{dU}
$$

After the integral transformation, the current time is the product of capacitance and impedance. Therefore, the intracellular water-holding time (IWHT) of plant leaves was represented as formula (23):

$$
\mathrm{IWHT}=\mathrm{IC} \times \mathrm{IZ}
$$

Further, the dynamic water transfer rate (WTR) of plant leaves was calculated as formula (24):

$$
\text { WTR }=\frac{\text { IWHC }}{\text { IWHT }}
$$

\section{The water utilization of $B$. papyrifera grown in two habitats}

Fig. 1 randomly listed the fitting curves and equations between the C (Fig. 1a), Z (Fig. 1b), Xc (Fig. 1c) of a leaf in $B$. papyrifera and clamping force. The results show that the relationships of the leaf $\mathrm{C}, \mathrm{Z}, \mathrm{Xc}$ and clamping force displayed good correlations. Subsequently, the fitting equation coefficients of both clamping force and the leaf $\mathrm{C}, \mathrm{Z}$, Xc in B. papyrifera which grown in the cultivated and moderate rocky desertification soils were calculated (Additional file 2), respectively. The correlation coefficients $\left(R^{2}\right)$ of the fitting equations of C-F, Z-F, and Xc-F for twelve leaves of two B. papyrifera were $0.7244 \sim 0.9962$ and $0.9283 \sim 0.9916,0.6791 \sim 0.9972$ and $0.9082 \sim 0.9974$, $0.8716 \sim 0.9986$ and $0.9730 \sim 0.9986$, respectively. Moreover, all $P$ values of them were lower than 0.0001 . This result further showed that the fitting equations of $\mathrm{C}-\mathrm{F}, \mathrm{Z}-\mathrm{F}$ and $\mathrm{Xc}-\mathrm{F}$ had good correlations and highlighted the potential of application. The water use parameters of two B. papyrifera were obtained using the corresponding parameters of the fitting equations (Table 1).

\section{Fig. 1.}

\section{Table 1}

As shown in Table 1, the leaf d, IC, IZ, IXc, IWHCs, IWHTs, WTRs and water contents in B. papyrifera of two habitats were significant difference $(p<0.05)$. The leaf IWHC, WTR and water contents of B. papyrifera in the cultivated soil were higher than that of the moderate rocky desertification soil. The results show that the water condition in the leaves of $B$. papyrifera grown in a better habitat was good, and the leaf IWHC and WTR were higher. Duo to the poor water condition in the leaves of B. papyrifera grown in the moderate rocky desertification soil, the water supply time (IWHT) of leaf organs was maintained by decreasing WTR so that it has a high IWHT. 
However, the leaf IWUEs in B. papyrifera of two habitats were no significant difference, the result shows that there was a little difference in the intracellular water use efficiency of leaves in the same plant.

The water utilization of the herbaceous and woody plants

The water use parameters of six plants are displayed in Table 2. The leaf IWHCs, WTRs and water contents of the tested plants were basically consistent, water contents of the herbaceous plants in the cultivated soil were significant $(p<0.05)$ higher than that of the woody plants in the moderate rocky desertification soil. However, the leaf IWHTs of different plants had no significant difference. Moreover, the leaf IWUE of $S$. scandens was significant $(p<0.05)$ higher than that of the other five plants and there was also a significant $(p<0.05)$ difference between I. batatas and the leftover four plants.

Table 2

\section{The water utilization of $S$. tuberosum and $C$. annuum}

As shown in Table 3, the leaf IWHC and WTR of $S$. tuberosum were significant $(p<0.05)$ higher than that of $C$. annuum. This result indicates that the good water condition of S. tuberosum leaves ensure its high WTR and growth rate, and the water supply time (IWHT) of $C$. annuиm leaves was increased by decreasing WTR. However, the leaf IWUE of $S$. tuberosum was significant $(p<0.05)$ lower than that of $C$. annuum. The result shows that the leaf IWUE was closely related to IWHT, the long IWHT ensured efficient utilization of the intracellular water.

Table 3

\section{Discussion}

That plants rapidly respond to environmental changes is accompanied by plant electrical activity, and that is considered to be the fastest response to exogenous stimuli [18-21]. The abiotic or biotic stimulus including drought, salt stimulation, cold stimulation, diseases and insect pests etc. can trigger various electrical activities of plants [10, 11, 22, 23]. Meanwhile, these stimulu can also cause changes of intracellular water status in plant leaves. Hence, the plant electrophysiological information can reflect the intracellular water status in plant leaves. Moreover, the electrophysiological information and membrane permeability of plant leaves are bound to change when they are subjected to clamping force. In addition, the work done by clamping force to plant leaves is equal to the changes in Gibbs free energy based on the first law of thermodynamics, and Nernst equation can be used to quantitatively describe the diffusion potential of dielectric substances inside and outside of cell membrane based on the third law of thermodynamics. According to these theories, the fitting equations of clamping force and leaf $\mathrm{C}, \mathrm{Z}$ and $\mathrm{Xc}$ were 
successfully established and they had good correlations and availability. Subsequently, the inherent (when clamping force is $0 \mathrm{~N}$ ) intracellular water use indexes of plant leaves were calculated through these equations. The results in this study show that plant electrophysiological information can effectively reflect the dynamic changes of intracellular water in plant leaves.

Plants growing in karst areas often suffer from various degrees of karst drought stresses (drought, high $\mathrm{pH}$, high contents of bicarbonate) [14]. In this study, the electrophysiological indexes (IC, IZ and IXc) of B. papyrifera grown in the cultivated and moderate rocky desertification soils were significant difference $(p<0.05)$, the result shows that different water habitats lead to conspicuous electrical activities among the same species of plants. Moreover, the results show that the leaves of B. papyrifera grown in the good water condition had high IWHC, WTR and water content, and the water supply time (IWHT) of leaves in the poor water condition was increased by decreasing WTR, as well as IWUE was a little difference of leaves in the same plant. This adaptation mechanism of plants for the adverse environment is consistent with the reality [24]. The herbaceous plants were more vulnerable to drought stress than woody plants duo to their shallow root distribution and inaccessibility to deep water [25, 26]. The results in this study display that the herbaceous plants in the cultivated soil have higher leaf IWHC, WTR and water contents, as compared to the woody plants in the moderate rocky desertification soil. These results indicate that the good water conditions of the herbaceous plants supported their vigorous life activities and it is coincident with the fact. However, the leaf IWHTs and IWUEs of different plants were a little difference which might be determined by the inherent characteristics of plants, and the significant leaf IWUE of S. scandens should be related to its high leaf biomass. In this study, S. tuberosum had higher leaf IWHC, WTR and lower IWUE, IWHT, as compared to C. annuum, these results are consistent with the biological fact that the biomass of S. tuberosum was larger than that of C. annuum [27, 28]. The results indicate that the novel monitoring method based on plant electrophysiological parameters of the intracellular water in plant leaves provided in this study had good availability.

Insertion of two electrodes into the stem or leaf is a traditional common approach to measure electrical signals of plants $[17,29]$. However, this method is instability, difficult to manipulate and low authenticity, and the plant electrical signals lacks representativeness, reproducibility and comparability due to needling injury can directly change the electrical signals, as well as different environment, measuring people and other factors [17, 30]. Moreover, the intracellular water transportation, water-holding and utilization information in plant leaves can't be obtained by simple $\mathrm{C}, \mathrm{Z}$ and $\mathrm{Xc}$ of electrical signals [9-11, 31]. In addition, the water information in plant leaves obtained by photosynthesis-transpiration, turgor pressure, water potential, spectrometry, stable oxygen and hydrogen isotope, and other methods still can't directly reflect the intracellular water information [1, 6-8]. In this study, the IC, IZ and IXc of plant leaves were calculated by the fitting equation coefficients of C-F, Z-F and Xc-F. Subsequently, the IWHC, 
IWUE, IWHT and WTR of the intracellular water use indexes in plant leaves based on the electrophysiological parameters were defined and calculated. The results indicate that these indexes perfectly revealed the life phenomenon and diversity of the intracellular water metabolism in various experimental plant leaves. Moreover, the indexes of the method in this study were obtained by the inherent electrical signals of plant leaves, which overcome the representativeness, instability and reproducibility of the traditional needing approach. Compared with previous approaches to obtain water information in plant, the method in this study has the advantages of being accurate, in situ, rapid, real time, highly reproducible and involves simple manipulations. The intracellular water use indexes IWHC, IWUE, IWHT and WTR based on plant electrophysiological parameters show promising potential to become a novel and routine monitoring method for intracellular water information.

\section{Conclusions}

The present work provided a novel method based on plant electrophysiological parameters for rapidly quantitative monitoring intracellular water information of plant leaves. The fitting equations of clamping force and leaf $\mathrm{C}, \mathrm{Z}$ and Xc were expectedly established on the basis of the first and third laws of thermodynamics, and which had good correlations. The intrinsic electrophysiological parameters (IC, IZ and IXc) of plant leaves were obtained by these equations. Subsequently, the IWHC, IWUE, IWHT and WTR of the intracellular water use indexes in plant leaves were defined and applied. The results show that the leaves of B. papyrifera in the cultivated soil had high IWHC, WTR and water contents. The leaf IWHC, WTR and water contents of the herbaceous plants in the cultivated soil were higher than that of the woody plants in the moderate rocky desertification soil. S. tuberosum had higher leaf IWHC, WTR and lower IWUE, IWHT, as compared to C. annuum. These indexes perfectly reveal and reflect the life phenomenon and diversity of the intracellular water metabolism in plant leaves and can be candidates for acquirement of plant intracellular water information.

\section{Methods}

\section{Plant materials}

Broussonetia papyrifera grown in two habitats of the cultivated and moderate rocky desertification soils at the comprehensive experimental station of Karst Ecology in Puding, Guizhou Province, Chinese Academy of Sciences $\left(26^{\circ} 37^{\prime}\right.$ N, $105^{\circ} 77^{\prime}$ E). Amygdalus persica L., Rhus chinensis Mill. and Ginkgo biloba L. grown in the moderate rocky desertification soil of the comprehensive experimental station, and Ipomoea batatas (L.) Lam., Senecio scandens Buch.-Ham. ex D. Don and Boehmeria penduliflora Wedd. ex Long grown in the cultivated soil of the 
field of the Guizhou Vocational College of Agriculture $\left(26^{\circ} 58^{\prime} \mathrm{N}, 106^{\circ} 43^{\prime} \mathrm{E}\right)$. Due to the vacuole volume can basically represent the water-holding capacity of plant leaves, and the vacuoles of the mature leaf cells account for $50 \% \sim 90 \%$ of the cell volume. Thus, mature leaves of fresh branches as experimental materials were measured. Firstly, mature leaves were taken from the third, fourth, and fifth leaf positions of each branch, and the fresh leaves were immediately soaked in water for $30 \mathrm{~min}$. And then, water on the surface of the leaves was removed. Four branches of each plant were measured.

301

\section{Leaf $\mathrm{C}, \mathrm{Z}$ and $\mathrm{Xc}$ measurement}

The leaf $\mathrm{C}$ and $\mathrm{Z}$ were measured using a LCR tester (model 6300, Gwinstek, Taiwan, China) with a frequency and voltage of $3.0 \mathrm{kHz}$ and $1.5 \mathrm{~V}$, respectively, as chosen by Zhang et al. [12] with modifications. The leaf center was clipped between the two electrodes in a self-made parallel-plate capacitor with a diameter of $7 \mathrm{~mm}$ (Fig. 2), the leaf $\mathrm{C}$ and $\mathrm{Z}$ at different clamping forces were continuously measured by adding iron blocks, and recorded 11-13 data each clamping force. Every mesophyll cell can be regarded as a concentric sphere capacitor, many aligned mesophyll cells make up the leaf capacitor. To ensure the voltage of each capacitor is consistent, the parallel connection mode of LCR is carried out. The leaf Xc was calculated according to Eq. (25):

$$
\mathrm{Xc}=\frac{1}{2 \pi \mathrm{fC}}
$$

where $\pi=3.1416, \mathrm{f}=$ frequency, $\mathrm{C}=$ physiological capacitance.

Fig. 2.

Additionally, leaf water contents were analyzed by the drying method, and the fresh weight of leaves was measured before soaking.

\section{Data analyses}

317 The data were analyzed using SPSS 18.0 (SPSS Inc., Chicago, IL, USA). A one-way analysis of variance followed by Duncan's test was performed.

\section{List of abbreviations}

C: capacitance, Z: impedance, Xc: capacitive reactance, F: clamping force, IC: intrinsic capacitance, IZ: intrinsic impedance, IXc: intrinsic capacitive reactance, IWHC: intracellular water-holding capacity, IWUE: intracellular water use efficiency, IWHT: intracellular water-holding time, WTR: water transfer rate. 
Supplementary information accompanies this paper at

Additional file 1. The relationship model construction of clamping force (F) and leaf Xc.

Additional file 2. The fitting equation parameters of B. papyrifera in two habitats

Additional file 3. Raw data

\section{Ethics approval and consent to participate}

Not applicable.

\section{Consent for publication}

Not applicable.

\section{Availability of data and materials}

The datasets generated and/or analysed during the current study are available in in this published article and its supplementary information files.

\section{Competing interests}

The authors declare that they have no conflicts of interest.

\section{Funding}

We thank the national natural science foundation of China (No. U1612441-2), the key technologies research and development program of China (No. 2016YFC0502607-02, 2016YFC0502602-5), the Science and technology innovation talent team of Guizhou Province [No. (2016)5618], and the scientific and technological achievement transformation project of Guizhou Province [No. (2017)4124] for supporting this research.

\section{Authors' contributions}

YYW and CZ designed research. CZ, YS, YD, YSW, and LF performed research. CZ and DX analyzed data. CZ and YYW wrote the paper. All authors read and approved the final manuscript.

\section{Acknowledgements}

We would like to thank the comprehensive experimental station of Karst Ecology in Puding, Guizhou Province, 
Chinese Academy of Sciences for providing the necessary support for this study, such as plant materials and corresponding premises, etc.

\section{Author details}

${ }^{1}$ Key Laboratory of Modern Agricultural Equipment and Technology, Ministry of Education, College of Agricultural Equipment and Engineering, Jiangsu University, Zhenjiang 212013, China; ${ }^{2}$ State Key Laboratory of Environmental Geochemistry, Institute of Geochemistry, Chinese Academy of Sciences, Guiyang 550081, China; ${ }^{3}$ Guizhou Vocational College of Agriculture, Qingzhen 551400, China

\section{References}

1. De Jong SM, Addink EAP, Hoogenboom Nijland W. The spectral response of Buxus sempervirens to different types of environmental stress, a laboratory experiment. Isprs. J. Photogramm. 2012; 74: 56-65.

2. De Jong, SM, Addink EA, Doelman JC. Detecting leaf-water content in Mediterranean trees using high-resolution spectrometry. Int. J. Appl. Earth. Obs. 2014; 27: 128-136.

3. Lisar SYS, Motafakkerazad R, Hossain MM, Rahman IMM. Water stress in plants: causes, effects and responses. In: Ismail, Md., Mofizur, R., Hiroshi, H. (Eds.), Water stress. Rijeka, Croatia. 2012. p.1-15.

4. Weng J. The role of active and passive water uptake in maintaining leaf water status and photosynthesis in tomato under water deficit. Plant. Prod. Sci. 2000; 3: 296-298.

5. Hopkins WG, Huner NPA. Introduction to Plant Physiology. 3rd ed. New York: John Wiley \& Sons Inc. 2004. p. 27.

6. Hamid A, Agata W, Kawamitsu Y. Photosynthesis, transpiration and water use efficiency in four cultivars of mungbean, Vigna radiata (L.) Wilczek. Photosynthetica. 1990; 24: 96-101.

7. González-Fernández AB, Rodríguez-Pérez JR, Marcelo V, Valenciano JB. Using field spectrometry and a plant probe accessory to determine leaf water content in commercial vineyards. Agr. Water. Manage. 2015; 156: 43-50.

8. Kahmen A, Simonin K, Tu KP, Merchant A, Arndt SK. Effects of environmental parameters, leaf physiological properties and leaf water relations on leaf water $\delta^{18} \mathrm{O}$ enrichment in different eucalyptus species. Plant. Cell. Environ. 2008; 31: 738-751. 213. 10. Gil PM, Gurovich L, Schaffer B, Alcayaga J, Rey S, Iturriaga R. Root to leaf electrical signaling in avocado in response to light and soil water content. J. Plant. Physiol. 2008; 165: 1070-1078. 

and photosynthetic characteristics in salt-stressed Brassica napus L. Chil. J. Agr. Res. 2017; 77: 78-86.

12. Zhang MM, Wu YY, Xing DK, Zhao K, Yu R. Rapid measurement of drought resistance in plants based on electrophysiological properties. Transactions of the ASABE. 2015; 58: 1441-1446.

13. Xing DK, Xu XJ, Wu YY, Liu YJ, Wu YS, Ni JH, Azeem A. Leaf tensity: a method for rapid determination of water requirement in formation in Brassica napus L. J. Plant. Interact. 2018; 13: 380-387.

14. Xing DK, Chen XL, Wu YY, Xu XJ, Chen Q, Li L, Zhang C. Rapid prediction of the re-watering time point of Orychophragmus violaceus L. based on the online monitoring of electrophysiological indexes. Sci. Hortic-Amsterdam. 2019; 256: 108642.

15. Lodish H, Berk A, Kaiser CA, Krieger M. Molecular Cell Biology. 5th ed. New York: W.H. Freeman and Company. 2004. p.35-41.

16. Buckley DJ, Lefebvre M, Meijer EGM, Brown DCW. A signal generator for electrofusion of plant protoplasts. Comput. Electron. Agr. 1990; 5: 179-185. 17. Wang ZY, Qin XH, Li JH, Fan LF, Zhou Q, Wang YQ, Zhao X, Xie CJ, Wang ZY, Huang L. Highly reproducible periodic electrical potential changes associated with salt tolerance in wheat plants. Environ. Exp. Bot. 2019; 160: $120-130$.

18. Choi WG, Hilleary R, Swanson SJ, Kim SH, Gilroy S. Rapid, long-distance electrical and calcium signaling in plants. Annu. Rev. Plant. Biol. 2016; 67: 287-307.

19. Gallé A, Lautner S, Flexas J, Fromm J. Environmental stimuli and physiological responses: The current view on electrical signaling. Environ. Exp. Bot. 2015; 114: 15-21.

20. Hedrich R, Salvador-Recatala V, Dreyer I. Electrical wiring and long-distance plant communication. Trends. Plant. Sci. 2016; 21376-387.

21. Yan X, Wang Z, Huang L, Wang C, Hou R, Xu Z, Qiao X. Research progress on electrical signals in higher plants. Progr. Nat. Sci. Mater. Int. 2009; 19: 531-541.

22. Favre P, Greppin H, Agosti RD. Accession-dependent action potentials in Arabidopsis. J. Plant. Physiol. 2011; 168: $653-660$. 23. Macedo FCO, Dziubinska H, Trebacz K, Oliveira RF, Moral RA. Action potentials in abscisic acid-deficient tomato mutant generated spontaneously and evoked by electrical stimulation. Acta. Physiol. Plant. 2015. p. 37. 24. Wu YY, Xing DK, Hang HT, Zhao K. Principles and Technology of Determination on Plant' Adaptation to Karst 416 Environment. Beijing: Science Press. 2019. p.191-191. 
418 resolves global organization of root functional traits. Nature. 2018; 555: 94-97.

419 26, Wang P, Huang K, Hu S. Distinct fine-root responses to precipitation changes in herbaceous and woody plants: a 420 meta-analysis. New. Phytol. 2020; 225: 1491-1499.

421 27. Chatterjee C, Gopal R, Dube BK. Impact of iron stress on biomass, yield, metabolism and quality of potato 422 (Solanum tuberosum L.). Sci. Hortic-Amsterdam. 2006; 108: 0-6.

423 28. Thapliyal A, Vasudevan P, Dastidar MG, Mamta T, Mishra S. Effects of irrigation with domestic wastewater on 424 productivity of green chili and soil status. Commun. Soil. Sci. Plant. 2013; 44: 1-17.

425 29. Zhao DJ, Wang ZY, Li J, Wen X, Liu A, Wang XD, Hou RF, Wang C, Huang L. Recording extracellular signals 426 in plants: a modeling and experimental study. Math. Comput. Model. 2013; 58: 556-563.

427 30. Volkov AG. Plant Electrophysiology: Theory and Methods. Springer. 2006. p. 25.

428 31. Jin SD, Zhang SF, Zheng RL. Diagnosis of drought from maize physiological electrical characteristics. 429 Transactions of the CSAE. 1999; 15: 91-95. (in Chinese) 


\section{$430 \quad$ Figure captions}

431 Fig. 1. Fitting equations of the relationship between leaf C (a), Z (b), Xc (c) and champing force (F)

432 Fig. 2. The experimental setup used in the study and schematic of the parallel-plate capacitor. $1=$ holder, $2=$

433 cystosepiment, $3=$ plate electrode, $4=$ electrical conductor, $5=$ iron block, $6=$ plastic rod, $7=$ bench holdfast.

434

435 Table captions

436 Table 1 The water use parameters of B. papyrifera in two habitats

437 Table 2 The water use parameters of six plants

438 Table 3 The water use parameters of two plants in the cultivated soil 
Figures

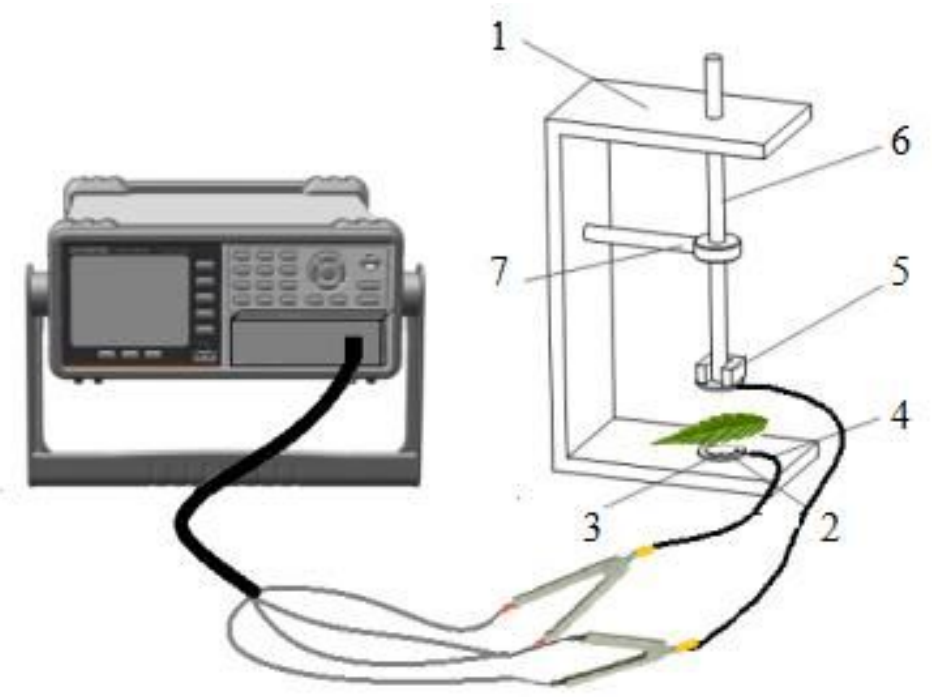

Figure 1

Fitting equations of the relationship between leaf $C(a), Z(b), X c(c)$ and champing force $(F)$ 

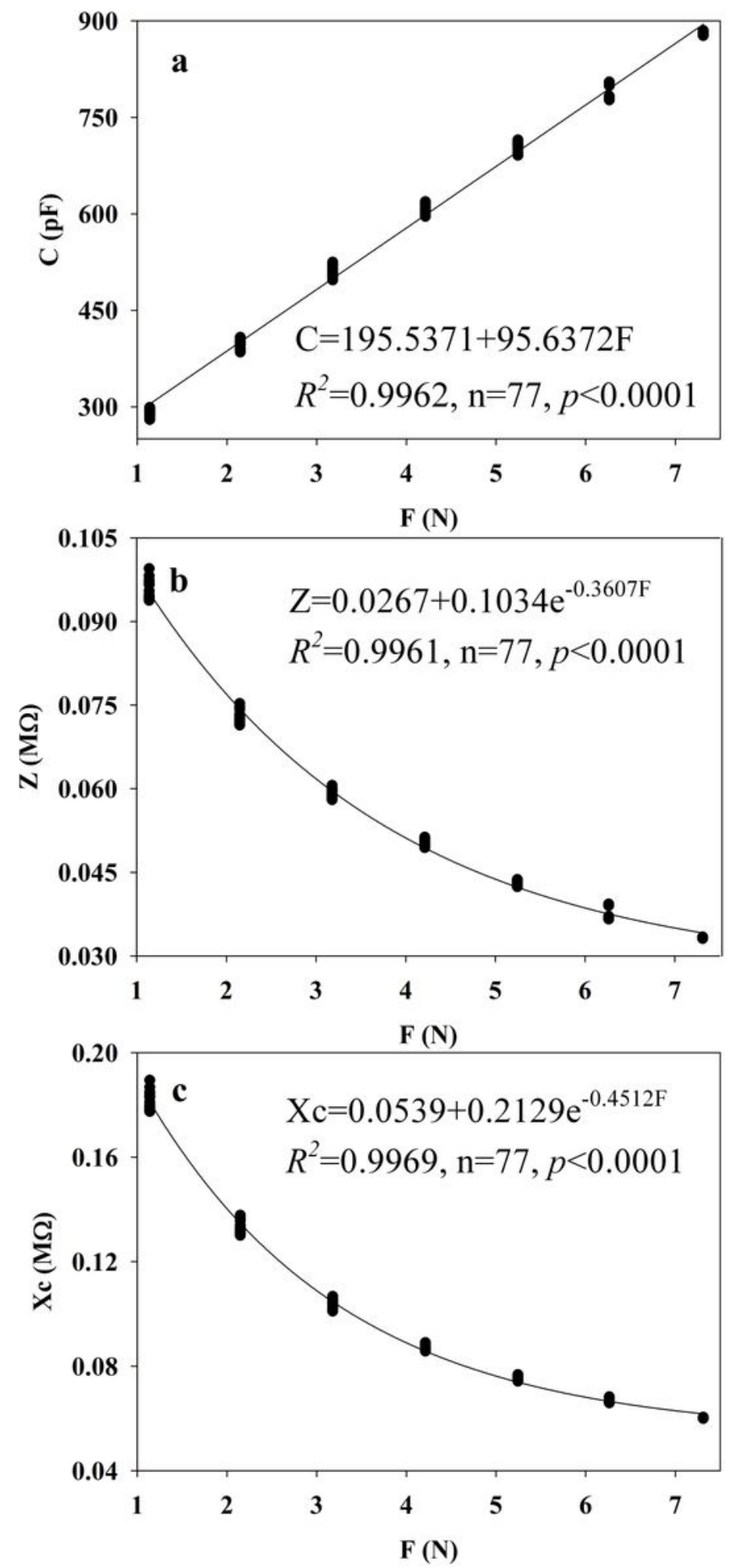

Figure 2

The experimental setup used in the study and schematic of the parallel-plate capacitor. $1=$ holder, $2=$ cystosepiment, $3=$ plate electrode, $4=$ electrical conductor, $5=$ iron block, $6=$ plastic rod, $7=$ bench holdfast. 
This is a list of supplementary files associated with this preprint. Click to download.

- 9.Additionalfile2.docx

- 8.Additionalfile1.docx

- 10.Additionalfile3RawData.xlsx 